\title{
Behavior of the High Temperature Conductivity of Polypyrrole Nitrate Films
}

\author{
Yongfang LI, ${ }^{\dagger}$ Renyuan QIAN, Kenichi IMAEDA, ${ }^{*}$ \\ and Hiroo INOKUCHI* \\ Institute of Chemistry, Academia Sinica, Beijing 100080, China \\ * Institute for Molecular Science, Myodaiji, Okazaki 444, Japan
}

(Received August 5, 1993)

\begin{abstract}
XPS, TGA, and conductivity measurement were performed on $\mathrm{PPy}\left(\mathrm{NO}_{3}{ }^{-}\right)$ films as prepared and those after treatment in a neutral aqueous solution. A characteristic decrease of conductivity accompanied by $c a .5 \%$ weight loss was observed for $\mathrm{PPy}\left(\mathrm{NO}_{3}{ }^{-}\right)$film as prepared in the temperature range of $c a .105-130^{\circ} \mathrm{C}$. Comparison with the results of $\mathrm{PPy}\left(\mathrm{NO}_{3}{ }^{-}\right)$films after treatment in a neutral solution offers further support for the existence of a protonated structure in the $\mathrm{PPy}\left(\mathrm{NO}_{3}{ }^{-}\right)$as prepared.
\end{abstract}

KEY WORDS Conducting Polymer / Polypyrrole / Conductivity / Thermogravimetric Analysis / Protonated Structure /

In the studies of conducting polypyrrole (PPy), the structure of oxidized conjugated chain with positive charges compensated by counter-anions have been generally accepted. ${ }^{1-3}$ However, in the study of the cyclic voltammetry of polypyrrole films two doping states of counter-ions, the shallowly trapped ions, and the deeply trapped ions, were suggested. ${ }^{4,5}$ The structure of PPy chains with the two trapped states was not clarified. Later, partial protonation of PPy chain was proposed based on the elemental composition of PPy treated in buffer solutions of different $\mathrm{pH}$ values. ${ }^{6}$ Recently, the authors studied the redox mechanisms of $\mathrm{PPy}\left(\mathrm{NO}_{3}{ }^{-}\right.$) (polypyrrole nitrate) films in the acidic, neutral and basic aqueous solutions respectively, and proposed the existence of two doping sites in PPy chains - the oxidized conjugated chain (site 1) and the protonated structure (site 2). ${ }^{7}$ The exact structure of the site 2 is not determined yet, but it was assumed in our previous paper as $^{7}$

\footnotetext{
$\dagger$ To whom correspondence should be addressed.
}

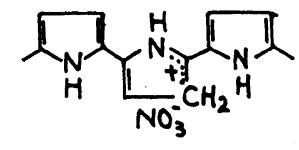

In this paper, XPS, TGA, and high temperature conductivity measurements of $\mathrm{PPy}\left(\mathrm{NO}_{3}{ }^{-}\right)$ films as prepared and those after treatment in neutral aqueous solution have been performed. The results give more evidence for the protonated structure.

\section{EXPERIMENTAL}

$\mathrm{PPy}\left(\mathrm{NO}_{3}{ }^{-}\right)$films were electrochemically polymerized at a constant current of $1.5 \mathrm{~mA}$ $\mathrm{cm}^{-1}$ in an aqueous solution of $0.1 \mathrm{M}$ pyrrole, $0.2 \mathrm{M} \mathrm{NaNO}_{3}$ at pH 3. Stainless steel plates were used both as the working electrode and the counter electrode. Thickness of the $\mathrm{PPy}\left(\mathrm{NO}_{3}{ }^{-}\right)$films prepared was ca. $20 \mu \mathrm{m}$.

Thermogravimetric analysis (TGA) was carried out with a Du Pont 9900 Thermal Analyser. The rate of temperature increased was 
$2 \mathrm{~K} \mathrm{~min}^{-1}$. Conductivity was measured by four probe method in a vacuum chamber with temperature increase at $c a .3 \mathrm{~K} \mathrm{~min}^{-1}$. Two samples, sample $\mathrm{A}-\mathrm{PPy}\left(\mathrm{NO}_{3}{ }^{-}\right)$film as prepared and sample $\mathrm{B}-\mathrm{PPy}\left(\mathrm{NO}_{3}{ }^{-}\right)$film after treatment in a neutral buffer solution $\left(0.025 \mathrm{M} \mathrm{KH}_{2} \mathrm{PO}_{4}+0.025 \mathrm{M} \mathrm{Na}_{2} \mathrm{HPO}_{4}\right)$ for 8 hours were investigated. Both sample $\mathrm{A}$ and sample B were dried in a drying oven at $50^{\circ} \mathrm{C}$ for 2 hours before measurement.

\section{RESULTS AND DISCUSSION}

$X P S$ of $\mathrm{PPy}\left(\mathrm{NO}_{3}{ }^{-}\right)$

Figure 1 shows the N1s XPS spectra of $\mathrm{PPy}\left(\mathrm{NO}_{3}{ }^{-}\right)$films of the sample A (solid line) and the sample B (broken line). The peak at $406.7 \mathrm{eV}$ belongs to the nitrogen in counteranion nitrate of $\mathrm{PPy}\left(\mathrm{NO}_{3}{ }^{-}\right)$and the peak at $399.8 \mathrm{eV}$ comes from the nitrogen of pyrrole ring. ${ }^{8,9}$ The $\mathrm{NO}_{3}{ }^{-}$peak of the sample $\mathrm{B}$ is much weaker than that of the sample $A$. Obviously, partial de-insertion of nitrate from PPy $\left(\mathrm{NO}_{3}{ }^{-}\right)$occurred when the PPy film as prepared was immersed in a neutral solution, in agreement with the result of elemental analysis. ${ }^{6,7}$

\section{Temperature Dependence of Conductivity}

At room temperature, the conductivities of samples A and B measured were 10-12 and $2-4 \mathrm{Scm}^{-1}$ (depending on the specimen cut from the sample) respectively, which means that the conductivity of $\operatorname{PPy}\left(\mathrm{NO}_{3}{ }^{-}\right)$decreas-

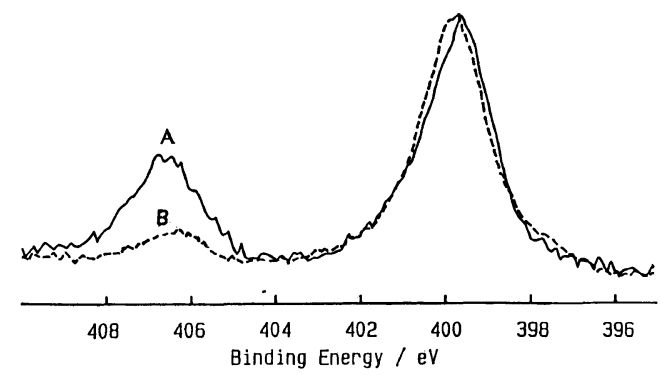

Figure 1. $\mathrm{N} 1 \mathrm{~s}$ XPS of $\mathrm{PPy}\left(\mathrm{NO}_{3}{ }^{-}\right)$films (A) as prepared and (B) after treatment in a neutral aqueous solution. ed by about 3-5 times after treatment in a neutral aqueous solution. The result is in line with previous findings. ${ }^{6}$ The temperature dependence of conductivity was studied in two temperature ranges, $100-290 \mathrm{~K}$ and 300 $460 \mathrm{~K}$. Below room temperature both sample $\mathrm{A}$ and sample B conform to a linear relation between $\log \sigma$ and $T^{-1 / 4}$ (Figure 2), indicating that the Mott variable range hopping mechanism of conduction in three dimensions ${ }^{10}$ remains unchanged after treatment in the neutral solution. However, above room temperature the conductivity behavior is different for the samples $\mathrm{A}$ and $\mathrm{B}$, as shown in Figure 3. The conductivity of sample A dropped sharply at $c a .105-130^{\circ} \mathrm{C}$, while that of sample B increased continuously with increasing temperature at that temperature range. Above $140^{\circ} \mathrm{C}$, the conductivity values

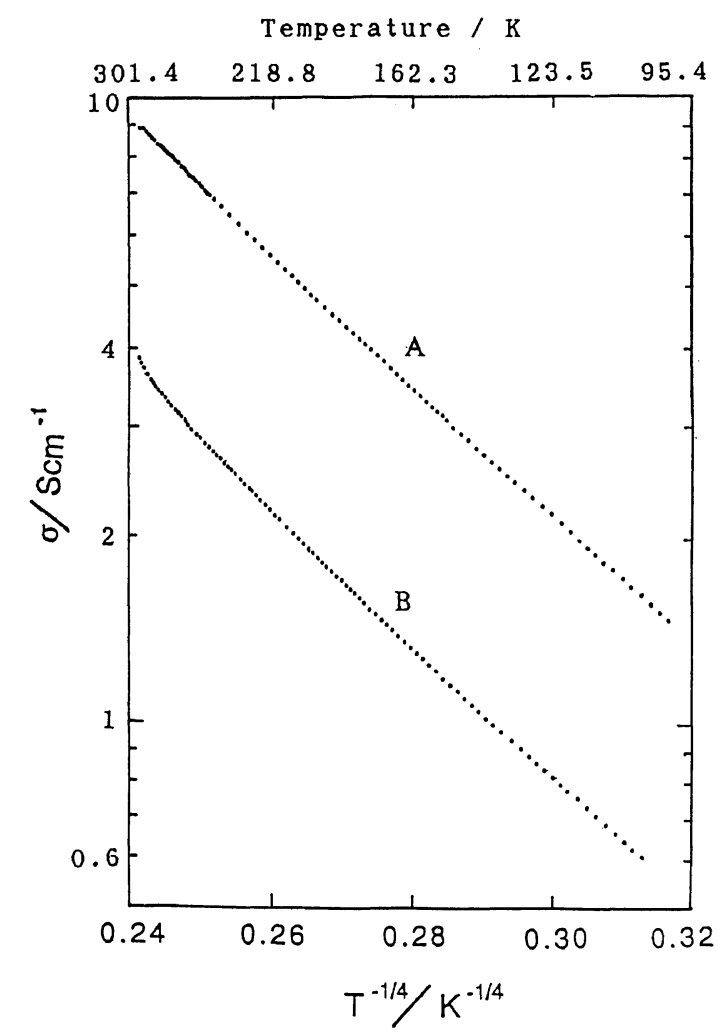

Figure 2. Mott plots of the conductivity of $\mathrm{PPy}\left(\mathrm{NO}_{3}{ }^{-}\right)$ films (A) as prepared and (B) after treatment in a neutral aqueous solution. 


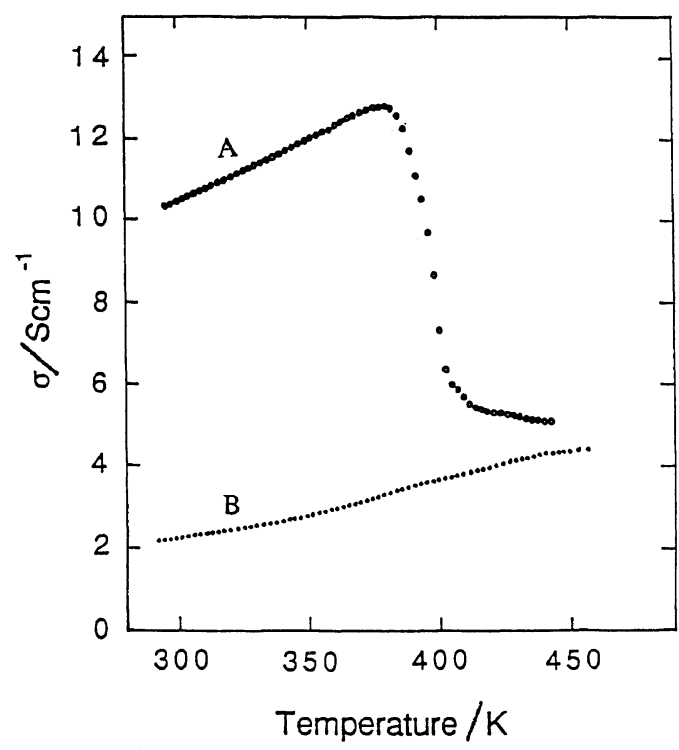

Figure 3. Temperature dependence of the conductivity of $\mathrm{PPy}\left(\mathrm{NO}_{3}{ }^{-}\right)$films (A) as prepared and (B) after treatment in a neutral aqueous solution.

of sample A seem to approach those of the sample B. It is logical to infer that at temperature above $130^{\circ} \mathrm{C}$ the structure of $\mathrm{PPy}\left(\mathrm{NO}_{3}{ }^{-}\right)$would be the same as that after treatment in a neutral solution, that means some de-insertion of the counter-anions occurred in the temperature range of 105 $130^{\circ} \mathrm{C}$.

\section{TGA Measurement}

In order to make the structural change at $105-130^{\circ} \mathrm{C}$ clear, thermogravimetric analysis was carried out for both samples. The TGA results are shown in Figure 4. A abrupt drop in weight $(\mathrm{ca} .5 \%)$ of the sample A, occurred just in the temperature range of about 105$130^{\circ} \mathrm{C}$. While the weight decrease of sample B proceeded evenly. From elemental analysis, the molar ratio of $\mathrm{NO}_{3}{ }^{-}$in $\mathrm{PPy}\left(\mathrm{NO}_{3}{ }^{-}\right)$as prepared is 0.22 per pyrrole unit, while that after TGA measurement from $50-130^{\circ} \mathrm{C}$ is 0.14 per pyrrole unit. Obviously, the weight loss at $105-130^{\circ} \mathrm{C}$ is due to the removal of $\mathrm{HNO}_{3}$. It should be noted that the TGA and conductivity behavior above room temperature

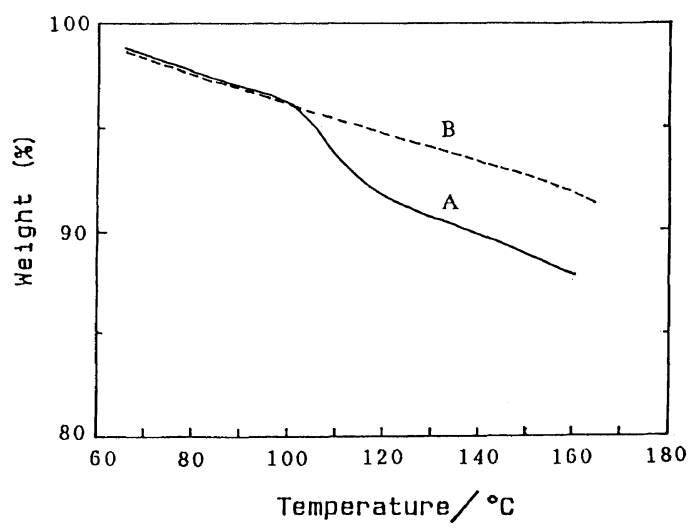

Figure 4. TGA curves of $\mathrm{PPy}\left(\mathrm{NO}_{3}{ }^{-}\right)$(A) as prepared and (B) after treatment in a neutral aqueous solution.

depends very much on the nature of counteranions involved. For example, $\mathrm{PPy}\left(\mathrm{TsO}^{-}\right)$, (polypyrrole doped with $p$-toluene sulphonate), the conductivity of the film as prepared increased with temperature continuously till more than $200^{\circ} \mathrm{C}$. There was no characteristic weight drop before $200^{\circ} \mathrm{C}$ in its TGA curve, in agreement with Truong et al. ${ }^{11}$

\section{CONCLUSION}

All the results from XPS, conductivity and TGA measurements strongly support the existence of protonated structure in $\mathrm{PPy}\left(\mathrm{NO}_{3}{ }^{-}\right)$ as prepared, which was proposed by the authors in previous papers. Deprotonation accompanied by partial deinsertion of the counter-anion takes place when the film is treated in a neutral aqueous solution or when it is heated above $105^{\circ} \mathrm{C}$. After deprotonation, the conductivity of the PPy film decreases by about 3-5 times, while the hopping mechanism of conduction remains unchanged.

Acknowledgment. This work was supported by National Natural Science Foundation of China and by Toyota Institute of Physics and Chemistry of Japan. 


\section{REFERENCES}

1. A. F. Diaz, J. I. Castillo, J. A. Logan, and W.-Y. Lee, J. Electroanal. Chem., 129, 115 (1981).

2. P. Pfluger, M. Krounbi, and G. B. Street, J. Chem. Phys., 78, 3212 (1983).

3. E. M. Genies and J. M. Pernaut, Synth. Met., 10, $117(1984 / 85)$.

4. J. Tanguy, N. Mermilliod, and M. Hoclet, J. Electrochem. Soc., 134, 795 (1987).

5. J. Tanguy and N. Mermilliod, Synth. Met., 21, 129 (1987).
6. Q. Pei and R. Qian, Synth. Met., 45, 35 (1991).

7. Y. Li and R. Qian, J. Electroanal. Chem, 362, 267 (1993).

8. K. Guo, Y. Li, C. Pan, and R. Qian, Acta Chimica Sinica, 48, 92 (1990).

9. P. Pfluger, M. Krounbi, G. B. Street, and G. Weiser, J. Chem. Phys., 78, 3212 (1983).

10. K. K. Kanazawa, A. F. Diaz, R. H. Geiss, W. D. Gill, J. F. Kwak, J. A. Logan, J. F. Robolt, and G. B. Street, J. Chem. Soc., Chem. Commun., 854(1979).

11. V.-T. Truong, B. C. Ennis, T. G. Tuener, and C. M. Jenden, Polym. International, 27, 187 (1992). 